\title{
THE INVESTMENT BANKERS CASE: THE USE OF SEMANTICS TO AVOID THE PER SE ILLEGALITY OF PRICE FIXING*
}

Section 1 of the Sherman Act condemns all contracts, combinations, and conspiracies in restraint of trade. ${ }^{1}$ The Supreme Court interpreted this language as prohibiting only unreasonable restrictions of competition without clearly explaining the method of determining whether a particular restriction is or is not unreasonable. ${ }^{2}$ But even as the Court reformulated the law in the Standard Oil case, it pointed out that certain contracts or other arrangements were inherently unreasonable, giving rise to an irrebuttable presumption of illegality. ${ }^{3}$ And a long line of decisions conclusively establishes that all price fixing agreements are illegal per se. ${ }^{4}$

\#United States v. Morgan, Civil No. 43-757, S.D.N.Y., October 14, 1953. This Note treats only one facet of the case. See note 10 infra.

1. The section reads in part, as follows: "Every contract, combination in the form of a trust or otherwise, or conspiracy, in restraint of trade or commerce among the ceveral States, or with foreign nations, is hereby declared to be illegal." 26 Srir. 209 (1890), 15 U.S.C. $\$ 1$ (1946).

2. Standard Oil Co. v. United States, 221 U.S. 1, $59-64$ (1911); United States v. American Tobacco Co., 221 U.S. 106, 17S-S0 (1911). The most cogent statement of the rule of reason is that of Mr. Justice Brandeis in Board of Trade of Chicago r. Unitcd States, 246 U.S. 231, 238 (1918) : "But the legality of an agreement or regulation cannut be determined by so simple a test, as whether it restrains competition. Every agrcement concerning trade, every regulation of trade, restrains. To bind, to restrain, is of their very essence. The true test of legality is whether the restraint imposed is such as merely regulates and perhaps thereby promotes competition or whether it is such as may suppress or even destroy competition. To determine that question the court must ordinarily consider the facts peculiar to the business to which the restraint is applied; its condition before and after the restraint was imposed; the nature of the restraint and its effect, actual or probable."

3. In distinguishing United States v. Trans-Missouri Freight Ass'n, 166 U.S. 290 (1897), and United States v. Joint Traffic Ass'n, 171 U.S. 505 (1S93), the Court declared that those "cases but decided that the nature and character of the contracts, creating as they did a conclusic'e presumption which brought them within the statute, such result was not to be disregarded by the substitution of a judicial appreciation of what the law ought to be for the plain judicial duty of enforcing the law as it was made." Standard Oil Co. v. United States, 221 U.S. 1, 65 (1911) (emphasis supplicd).

4. "Thus for over forty years this Court has consistently and without deviation adhered to the principle that price fixing agreements are unlawful for se under the Sherman Act and that no showing of so-called competitive abuses or evils which tho"e agreements were designed to eliminate or alleviate may be interposed as a defence." United States v. Socony-Vacuum Oil Co., 310 U.S. 150, 218 (1940). Accord, Unitcd States v. New Wrinkle, Inc, 342 U.S. 371 (1952); Schwegmann Bros. v. Calvert Distillers Corp., 341 U.S. 385 (1951) ; Kiefer-Stewart Co. v. Seagram \& Sons, Inc., 340 U.S. 211 (1951); United States v. National Ass'n of Real Estate Lts., 339 C.S. 455 (1950) ; Mandeville Island Farms v. American Crystal Sugar Co., 334 U.S. 219 (1943); United States v. Paramount Pictures, Inc., 334 U.S. 131 (1948); United States v. L.s. 
In the recent case of United States $v$. Morgan, ${ }^{\square}$ the Government charged that three types of contracts commonly used by underwriting syndicates in distributing new issues of securities are illegal per se. ${ }^{B}$ Agreements among members of an underwriting syndicate to maintain the public offering price during the period of distribution were attacked as horizontal price fixing.?

Gypsum Co., 333 U.S. 364 (1948) ; United States v. Line Material Co., 333 U.S. 287 (1948) ; United States v. Frankfort Distilleries, Inc., 323 U.S. 293 (1945); United States v. Bausch \& Lomb Optical Co., 321 U.S. 707 (1944); United States v. Masonite Corp., 316 U.S. 265 (1942); United States v. Univis Lens Co., 316 U.S. 241 (1942) ; Ethyl Gasoline Corp. v. United States, 309 U.S. 436 (1940) ; United States v. Trenton Potteries Co., 273 U.S. 392 (1927). See Comment, The Per Se Illegality of Price-Fixing-Sans Power, Purpose, or Effect, 19 U. of CHI. L. Rev. 837 (1952).

Neither Appalachian Coals, Inc. v. United States, 288 U.S. 344 (1933), nor Board of Trade of Chicago v. United States, 246 U.S. 231 (1918), involves deviations from the rule that all price fixing agreements are illegal per se. Board of Tradc of Chicago involved the legality of a Board rule which prohibited its members from "offering to purchase, during the period between the close of the call and the opening of the session on the next business day, any wheat, corn, or rye 'to arrive' at a price other than the closing bid at the call." Id. at 237. The closing bid was set by competitive forces in the market. Id. at 239-40. The Court emphasized that "the government . . . made no attempt to show the rule was designed to or that it had the effect . . . of raising or depressing prices," id. at 238, and stated that it viewed the rule as a restriction on the period of competitive price fixing rather than as a price fixing agreement. "Every Board of Trade ... imposes some restraint on the conduct of business by its members. Those relating to the hours in which business may be done are common; and they make a special appeal where, as here, they tend to shorten the working day or, at least, limit the period of most exacting activity." Id. at 241 (emphasis supplied). See also $i d$. at 239 . Thus, since neither the purpose nor the effect of the rule was to set prices, the rule was not a per se violation of $\S 1$. Appalachian Coals is distinguishable on similar grounds. See note 34 infra.

Moreover, the Supreme Court has repeatedly defined price fixing in very broad terms. See, e.g., United States v. Socony-Vacuum Oil Co., 310 U.S. 150, 222-3 (1940) : "Hence prices are fixed within. the meaning of the ... [Sherman Act] if the range within which purchases or sales will be made is agreed upon, if the prices paid or charged are to be at a certain level or on ascending or descending scales, if they are to be uniform, or if by various formulae they are related to the market prices. They are fixed because they are agreed upon. And the fact that, as here, they are fixed at the fair going market price is immaterial." However one circuit court has found this definition too vague to be helpful. See Cargill, Inc. v. Board of Trade of Chicago, 164 F.2d 820, 823 (7th Cir. 1947).

5. Civil No. 43-757, S.D.N.Y., October 14, 1953.

6. The Government did not attack the legality of the syndicate system; it merely attacked the resale price agreements usually employed by such syndicates. Bricf for United States, pp. 11, 37-40, 76-80, United States v. Morgan, Civil No. 43-757, S.D.N.Y., October 14, 1953.

The syndicate method of security distribution is explained and evaluated in Comment, Price Maintenance in the Distribution of Neve Securities, 56 YALE L.J. 333 (1947). Sce National Ass'n of Securities Dealers, Inc., 19 S.E.C. 424, 451-9 (1945). See also Parlin \& Everett, The Stabilization of Security Prices, 49 CoL. L. Rev. 607 (1949).

7. Brief for United States, pp. 6-8, 16-22, United States v. Morgan, supra note 6. Horizontal price fixing has been consistently condemned by the Supreme Court since the early railroad rate bureau cases, United States v. Joint Traffic Ass'n, 171 U.S. 505 
Agreements between underwriters and dealers in the selling group fixing the price at which dealers may resell the securities were attacked as resale price maintenance agreements. ${ }^{8}$ And agreements authorizing the syndicate manager to repurchase securities which appear during the period of distribution at or below the agreed public offering price were attacked as agreements authorizing a means of stabilizing prices. ${ }^{9}$

(1S98) : United States v. Trans-Missouri Freight Ass'n, 160 U.S. 290 (1897). See, c.t., Kiefer-Stewart Co. v. Seagram \& Sons, Inc, 340 U.S. 211 (1951) Iagreement among producers to maintain maximum resale prices on their preducts); Lnited States v. National Ass'n of Real Estate Bds., 339 U.S. 485 (1950) (agreement among real estate brokers fixing minimum brokerage fees); ('nited States v. Socony-Vacuum Oil Co., 310 U.S. 150 (1940) (agrcement among major refiners to "stabilize" the price of gasoline in spot markets by purchasing the "distress" gasoline of independent refiners); United States v. Trenton Potteries Co., 273 C.S. 392 (1927) (agreement among manufacturers and distributors of vitreous $p$ ttery tathros $m$ fixtures to fix prices and limit outlets).

S. Brief for United States, pp. 6-8, 16, 22-30, United States v. Morgan, Civil No. 43757, S.D.N.Y., October 14, 1953. The leading case condemning resale price maintenance agreements is Dr. Miles Medical Co. v. Park \& Sons Co., 200 U.S. 373 (1911) (agresments between manufacturer and dealers setting the wholesale and rotail rorice of proprietary medicines). See also United States v. Paramount Pictures, Inc, 334 L.S. 131 (1948) (agreements between producers, distributors, and exhibitors setting minimum admission prices); United States v. Bausch \& Lomb Optical Co., 321 C.S. 707 (1944) (agreements between distributor and its wholesalers and retailers setting resale rrice of unpatented lenses) ; United States v. Univis Lens Co., 316 U.S. 241 (1942) (agreement between owner of patents and distributor-finishers setting the resale price of finished lenses); Ethyl Gasoline Corp. v. United States, 309 U.S. 436 (1940) (agrecment between patentee, licensee-refiners, and jobbers controlling the price pulicies of jobbers). But cf. United States v. General Electric Co, 272 U.S. 476 (1926) (patentee allowed to sct resale prices of its licensee and bona fide agents).

Resale price maintenance contracts will escape judicial cundemnation if they can bs brought within the provisions of the Miller-Tydings Amendment to $\$ 1$ of the Sherman Act. 50 STAT. 693 (1937), 15 U.S.C. $\$ 1$ (1946). However this amendment is construsd strictly against those seeking its protection. See, c.g., Schwegmann liros. v. Calvert Distillers Corp., 341 U.S. 384 (1951) ; United States v. Univis Lens Co., 316 C.S. 241 (1942). And agreements among competitors, such as are involved in the instant ase, are specifically exempt from the amendment. United States v. Franlsfort Distilleries, Inc, 324 U.S. 293, 296-7 (1945). Furthermore, the SEC has already stated that it believes the amendment does not apply to securities. National Ass'n of Sccurities Dealers, Inc, 19 S.E.C. 424,446 n.35 (1945).

9. Brief for United States, pp. 6-8, 16, 30-2, United States v. Morgan, Civil No. 43757, S.D.N.Y., October 14, 1953. See Lnited States v. Socony-Vacuum Oil Co., 310 L.S. $150,223(1940)$ : "[P]urchases at or under the market are one species of price-fixing. In this case the result was to place a floor under the market-a foor which served the function of increasing the stability and firmness of market prices. That was reneatcdly characterized in this case as stabilization. But in terms of market operations stabilization is but one form of manipulation. ... Under the Sherman Act a combination formed for the purpose and with the effect of ... stabilizing the price of a commodity in interstate or foreign commerce is illegal per se" Cf. Kiefer-Stewart Co. v. Seagram \& Sons, Inr.. 340 U.S. 211, 213 (1951) (reaffirming Socony on stabilization); Suift \& Co. v. C'nitcd States, 196 U.S. 375 (1905) (restraining a combination from raising, lowering, ur fising prices). 
Judge Medina held that the legality of such contracts in general was not properly in issue, ${ }^{10}$ but felt compelled to state his views in dictum. ${ }^{11}$ The court viewed participants in syndicate agreements as engaged in an ad hoc common enterprise formed for the purpose of performing a service for the issuer. $^{12}$ Thus they are to be regarded as joint venturers rather than as competitors in handling issues subject to syndicate agreements. ${ }^{13}$ Judge Medina declared that direct limitations on price competition among stuch joint venturers is not price fixing within the meaning of the Sherman Act. ${ }^{14}$ Rather, they should be regarded as ancillary to the main purpose of the joint venture: the orderly distribution of a new issue of securities in behalf of the issuer.15 And its legality must be judicially determined by the measure of protection needed to fulfill that purpose. ${ }^{16}$ Judge Medina concluded that agreements containing provisions for a fixed offering price, price maintenance, and stabilization might be entered into and performed under such circumstances that they would amount to an unlawful suppression of competition but that the mere making of such agreements is not unlawful per se. ${ }^{17}$

It is difficult to accept the court's "joint venture" theory. ${ }^{18}$ The members

10. United States v. Morgan, Civil No. 43-757, S.D.N.Y., October 14, 1953 [pp. 12023 Record Press].

The complaint charged an integrated, overall conspiracy on the part of 17 firms to eliminate competition and monopolize the cream of the investment banking business. The pre-trial and trial proceedings took approximately 6 years. In a 417 page opinion Judge Medina dismissed the complaint after the Government had presented its case, on the ground that a prima facie case of conspiracy had not been made out. Id. at 414-17. This Note is concerned only with that part of the opinion dealing with the syndicate price fixing agreements.

11. "True it is that the questions involved are important to the investment banking industry as a whole; ... these questions have never before been decided by any court; and much time and effort have been expended during this long trial in extensive and scholarly research, the submission of voluminous briefs and in prolonged and helpful argument by counsel." Id. at 121. "The following discussion of the questions of law affecting the syndicate system in general, is by way of dictum." Id. at 123.

12. Id. at $128,129-30,131$.

13. Id. at $128-9$.

14. Id. at $129,138-40$.

15. Id. at 140

16. Id. at 132-3, 149. Cf. United States v. Addyston Pipe \& Steel Co., 85 Fed. 271, 282-3, 290-1 (6th Cir. 1898).

17. See United States v. Morgan, Civil No. 43-757, S.D.N.Y., October 14, 1953 [pp. 132-3, 149 Record Press].

18. The SEC adopted a similar theory in National Ass'n of Securities Dealers, Inc., 19 S.E.C. $424,446-59,462-4,486-9$ (1945). However, in that case the SEC set aside disciplinary action by the NASD against members of the NASD who had sold bonds below the price schedules contained in the syndicate agreements. The SEC held that the disciplinary powers of the NASD were limited by the requirement of $\& 15 \mathrm{~A}(\mathrm{~b})(7)$ of the Securities Exchange Act that the association rules be designed to remove impediments to the mechanism of a free and open market. Id. at 433-6. The Commission then continued: "It is axiomatic that a market is not 'free and open' with respect to a security whose price is fixed by unilateral action of the sellers. . . We cannot doubt 
of the syndicate do not possess the normal attributes of joint venturers. ${ }^{19}$ Most syndicate agreements specifically state that the underwriters are not to be so regarded. ${ }^{20}$ And since title passes from the underwriters to the members of the selling group, the dealers cannot be viewed as engaged in a joint renture with the underwriters. ${ }^{21}$ Furthermore, even if the underwriters and dealers were engaged in a joint venture, the fact would be immaterial. The Sherman Act is concerned with the substance of an agreement, not its form. $m$ And no amount of judicial semantics can change the fact that underwriters and dealers

that price-maintenance and fixed discount contracts are designed to restrict the frce movement of price during distribution, and are per se impediments to . . . a irce and open market'. ..."Id. at 440. The Commission then went on to point out that the reasonableness and necessity of the restraints were irrelevant to the issue of the NASD's rule-making and disciplinary powers because Congress had limitcd those powers by statute. Id. at 442-5. Thus the SEC's rationale of its holding in the case contradicts its dicta on the legality of syndicate price fixing agreements under the Sherman Act. See also id. at $468-9,490$.

19. The members of the syndicate do not share the profits or losses on the sale of the securities. The individual members of the syndicate purchase a share of the sccurities. When they sell those securities they are selling their own property, and the yrofit or loss of each sale is the profit or loss of the individual underwriter or dealer. Yet one of the essential characteristics of a joint venture-which is essentially a partnership, limited in scope and duration-is profit sharing. CRLNe, Partikensurp $\$ \$ 35,14$ (1952).

20. The disclaimer is intended to render each underwriter immune from liability under the Securities Exchange Act of 1934, 48 St.IT. \&2 (1933), as amended, 43 STat. 907-0S (1934), 15 U.S.C. $\$ 77 \mathrm{~K}$ (1946), for that part of the issue distributed by the other members of the syndicate. United States v. MIorgan, Civil No. 43-757, S.D.N.Y., October 14, 1953 [pp. 41-2 Record Press]. Section 206(d) of that Act imposes a civil liability on each underwriter, for any omission or misstatement of a material fact in the registration, equal to the total price at which the securities underwritten and distributca by him were offered to the public. Ibid. The tax on transfers of securities is another reason the underwriters purchase securities from the issuer in severalty rather than jointly. Ibid.

21. The passage of title from the underwriters to the members of the selling group cannot be regarded as "a purely fortuitous and incidental feature" Id. at 131. The Supreme Court has stated that passage of title is a fundamental fact in antitrust litigation. Sce, c.g., Dr. Míles Medical Co. v. Park \& Sons Co., 220 U.S. 373, 407, 409 (1911) : "The agreements are designed to maintain prices, after the complainant has farted wilh the lille to the articles, and to prevent competition among those who trade in them. ... The complainant having sold its product at prices satisfactory to itself, the public is entitled to whatever advantage may be derived from competition in the subsequent traffic." (emphasis supplied).

Judge Medina's view is similar to that which has been rejected by the Supreme Court in developing the doctrine of intra-enterprise conspiracy. In those cases the Court repeatedly refused to overlook the fact of separate corporate entity. See Comment, 63 YALE L.J. 372 (1953).

22. "[A]11 the difficulties suggested by the mere form in which the assailed transactions are clothed become of no moment. ... [T] he generic desigmation of the first and second sections of the law, when taken together, embraced every conceivable act which could possibly come within the spirit or purpose of the prohibitions of the law, without regard to the garb in which such acts were clothed." United States v. Amerian Tobscco Co., 221 U.S. 106, 180-1 (1911). 
have agreed to maintain a fixed price for the securities they severally own during the period of distribution. The Supreme Court has repeatedly set aside elaborate "licensing" 23 and "agency" 24 contracts because they were in reality mere price fixing agreements. ${ }^{25}$ And, in the Timken case, the Court specifically rejected a contention that price fixing could be justified as ancillary to a joint venture in which the defendants were engaged. ${ }^{\mathbf{2 0}}$

Judge Medina's view that members of the syndicate are merely performing a service for this issuer ${ }^{27}$ is, at best, irrelevant. The issuer sells the securities to the syndicate and receives payment at the time of the sale. ${ }^{28}$ Thus, when the underwriters and dealers sell the issue to the public, they are selling their own merchandise. And in agreeing to maintain a fixed price for that merchandise they are attempting to escape the risk of lower profits which might result from allowing individual members of the syndicate to sell at competitive prices. ${ }^{29}$ Moreover, even if the defendants can be viewed as merely performing a service for the issuer, that fact would be irrelevant to the legality of the syndicate agreements. The syndicate's agreements fix the price members are to receive for their "services" by fixing the spread between the price paid the issuer and the price maintained to the public. And the Supreme Court has repeatedly held that price fixing of services is just as offensive to the Sherman Act as price fixing of goods. ${ }^{30}$

23. E.g., Ethyl Gasoline Corp. v. United States, 309 U.S. 436 (1940).

24. E.g., United States v. Masonite Corp., 316 U.S. 265 (1942).

25. "So far as the Sherman Act is concerned, the result must turn not on the skill with which counsel has manipulated the concepts of 'sale' and 'agency' but on the significance of the business practices in terms of restraint of trade." Id. at 280.

26. "Nor do we find any support in reason or authority for the proposition that agreements between legally separate persons and companies to suppress competition among themselves and others can be justified by labeling the project a 'joint venture.' Perhaps every agreement and combination to restrain trade could be so labeled." Timken Roller Bearing Co. v. United States, 341 U.S. 593, 598 (1951). See also id. at 597-8.

27. United States v. Morgan, Civil No. 43-757, S.D.N.Y., October 14, 1953 [pp. 128-31 Record Press].

28. See, e.g., the description of the Public Service Co. of Indiana underwriting in National Ass'n of Securities Dealers, Inc., 19 S.E.C. 424, 427, 456-7 (1945).

29. The members of the syndicate often attempt to sell their securities to the same investor. Transcript of Record, pp. 16,402, 17,929, United States v. Morgan, Civil No. 43-757, S.D.N.Y., October 14, 1953. Apparently Judge Medina regarded an agreement between such competitive sellers to maintain a uniform price to all custonters as an agreement between quasi-partners not to cut each other's throat. United States v. Morgan, supra [p. 129 Record Press]. Yet this is a perennial defense of price fixers, and it has always been rejected by the Supreme Court. See notes $42-6$ infra.

30. "The fixing of prices and other unreasonable restraints have been consistently condemned in the case of services as well as goods. Transportation services . . . cleaning, dyeing, and renovating wearing apparel .... the procurement of medical and hospital services.... the furnishing of news or advertising services ... -these indicate the range of business activities that have been held to be covered by the Act." United States v. National Ass'n of Real Estate Bds., 339 U.S. 485, 491 (1950) (services of a real estate broker). 
As an alternative ground for deciding that the syndicate agreements were not price fixing within the meaning of the Sherman Act, the court apparently adopted the defendants' contention that price fixing is not illegal per se unless done by persons controlling the general market. ${ }^{31}$ Securities, it reasoned, are not bought and sold as unique commodities with special utilitarian functions; they are purchased for investment on the basis of quality and yield. Thus the new issue distributed by the syndicate is in competition with every seasoned security of comparable quality, and members of the syndicate are in competition with every other dealer in such securities. Since any particular issue is a tiny fraction of the general market in comparable securities, the syndicate can have no effect whatsoever on general market prices. ${ }^{32}$ Therefore, price fixing among the members of the syndicate in connection with one issue, and for a limited period of time, is not illegal per se but subject to the rule of reason. ${ }^{33}$

While direct limitations on price competition among persons who as a group are unable to affect market prices may be subject to the rule of reason, ${ }^{3 /}$ the Supreme Court has specifically held that control of the general market is unnecessary to render such agreements illegal per se..35 All that is necessary to violate Section 1 is the power to affect prices in an appreciable segment of

31. United States v. Morgan, Civil No. 43-757, S.D.N.Y., October 14, 1953 [pp. 12930 Record Press].

32. Ibid. Sec National Ass'n of Securities Dealers, Inc, 19 S.E.C. 424, 451, 497.8 (1945).

33. United States v. Morgan, Civil No. 43-757, S.D.N.Y., Octuluer 14, 1953 [مr. 123, 132-3 Record Press].

34. In Appalachian Coals, Inc., v. United States, 288 U.S. 344 (1933), the Surreme Court upheld the validity of an exclusive selling agency organized by a gruup of bituminous coal producers. The case is clearly distinguishable from the instant case. In A pralostions the Court held that the plan did not contemplate the fixing of market irices. Id. at 373 . In the instant case the agreements do contemplate the fixing of the market price of the issue during the period of distribution. In Appalachian the Court held the selling agency had no power to affect market prices directly. Id. at 373,375 . In the instant case the syndicate has the power directly to affect the price of the issue during the periud of distribution. In Appalachian the selling agency was not authorized to attempt to statilize market prices. Id. at 367 . In the instant case the manager of the syndiente is specifically authorized to attempt to stabilize the market price of the issue during the period of distribution. And, finally, in Appalachian the Court directed the district court to retain jurisdiction in order to take further action if the selling agency developsd sufficient power to affeet prices directly. Id. at $377-8$.

The Supreme Court distinguished Appalachion on these grounds in Unitsd States v. Socony-Vacuum Oil Co., 310 U.S. 150, 214-17 (1940).

35. "[T] the thrust of the rule is deeper and reaches more than monopoly puwer. Any combination which tampers with price structures is engaged in an unlawful activity. Even though the members of the price-fixing group were in no position to control the marlict, to the extent that they raised, lowered, or stabilized prices they would be dircetly interfering with the free play of market forces. The Act places all such schemes beyond the pale. ..."Id. at 221. See id. at 224, 243-8. 
the market. ${ }^{36}$ And there can be no doubt that the syndicate has sufficient power to affect the price of a given issue during the period of distribution. In fact defendants argued, and the court concluded, that it was necessary to allow the syndicate to stabilize the price of new securities in order to insure their orderly distribution. ${ }^{37}$ The antitrust laws condemn all such schemes. ${ }^{38}$

Whatever may be the peculiar problems and characteristics of investment banking, ${ }^{30}$ the Sherman Act establishes a uniform rule applicable to all businesses. ${ }^{40}$ Any "combination formed for the purpose and with the effect of raising, depressing, fixing, pegging, or stabilizing the price of a commodity in interstate or foreign commerce is illegal per se." 41 Such agreements cannot be justified on the ground of business necessity, ${ }^{42}$ suppression of competitive

36. "Proof that a combination was formed for the purpose of fixing prices and that it caused them to be fixed or contributed to that result is proof of the completion of a pricefixing conspiracy under $\S 1$ of the Act." Ibid. (emphasis supplied). See also id. at 219-20, 244-7.

There is no need to prove that the members of the syndicate were able to affect the general market price of all securities; it is sufficient that they were able to affect the price of the securities subject to the syndicate agreements. "Section 1 of the Act outlaws unreasonable restraints on interstate commerce, regardless of the amount of the commerce affected. . . . Likewise irrelevant is the importance of the interstate commerce affected in relation to the entire amount of that type of commerce in the United States. . . . [The defendant's] relative position in the field of cab production has no necessary relation to [its] ability ... to conspire to monopolize or restrain, in violation of the Act, an appreciable segment of interstate cab sales. An allegation that such a segment has becn or may be monopolized or restrained is sufficient." United States v. Yellow Cab Co., 302 U.S. 218, 225-6 (1947). See also United States v. Paramount Pictures, 334 U.S. 131, 173 (1948) ; United States v. Soconoy-Vacuum Oil Co., 310 U.S. 150, 224 (1940).

Moreover, price fixing agreements may well be illegal per se even though the conspirators have $n o$ power to affect prices. The Supreme Court has specifically said so in dictum: "A conspiracy to fix prices violates $\S 1$ of the Act though no overt act is shown, though it is not established that the conspirators had the means available for accomplishment of their objective, and though the conspiracy embraced but a part of the interstate or foreign commerce in the commodity." Id. at 224-5 n.59. See Comment, The Per Se Illegality of Price-Fixing-Sans Power, Purpose, or Effect, 19 U. of CHr. L. REv. 837 (1952). On the desirability of such a rule, compare this Comment, with Jaffe \& Tobriner, The Legality of Price Fixing Agreements, 45 Hanv. L. Rev. 1164, 1181 (1932).

37. United States v. Morgan, Civil No. 43-757, S.D.N.Y., October 14, 1953 [pp. 129. 31 Record Press]. The same argument was accepted by the SEC in National Ass'n of Securities Dealers, Inc., 19 S.E.C. 424, 442, 456-8, 492-3 (1945). "Orderly" distribution means distribution at a non-competitive price. Id. at 468 .

38. See note 35 supra.

39. See note 37 supra. It is difficult to understand why the fact that it may be necessary for a reasonable number of underwriters to combine in order to raise sufficient capital to purchase a new issue from the issuer also makes it necessary for the underwriters to agree on the price at which they will sell the securities they individually own. Sec notes 19-21, 28 supra.

40. United States v. Socony-Vacuum Oil Co., 310 U.S. 150, 222 (1940).

41. Id. at 223.

42. E.g., Eastern States Retail Lumber Dealers' Ass'n v. United States, 234 U.S. 600,613 (1914). 
abuses, ${ }^{43}$ or other benefits to the public. ${ }^{44}$ And the reasonableness of the prices set is irrelevant. ${ }^{40}$ Only specific legislative exemption can save such an agreement from judicial condemnation $;^{46}$ Congress has twice refused to grant exemption to these syndicate agreements. ${ }^{27}$ Lodged with the lower courts is a duty to apply the law, even in dicta, as the Supreme Court has repeatedly declared it rather than as they feel it ought to be.48

43. E.g., United States v. Socony-Vacuum Oil Co., 310 U.S. 150, 220.21 (1910).

44. "It is not for the courts to determine whether in particular settings, price-fixing serves an honorable or worthy end. An agreement, shown either by adherence to a price schedule or by proof of consensual action fixing the uniform or minimum price, is itcelf illegal under the Sherman Act, no matter what end it was designed to serve. That is the teaching of an unbroken line of decisions." United States v. National Ass'n of Real Estate Bds., 339 U.S. 485, 489 (1950).

45. "Beginning with United States v. Trans-Missouri Freight Asseciation . . . and United States v. Joint Traffic Association . . . it has since often been decidcd and always assumed that uniform price fixing ... is prohibited by the Sherman Law, despite the reasonableness of the particular prices agreed upon." United States v. Trenton Putteries Co., 273 U.S. 392, 398 (1927).

46. "Congress has not left with us the determination of whether or not particular price-fixing schemes are wise or unwise, healthy or destructive. It has not frrmitted the age-old cry of ruinous competition and competitive evils to be a defense to pricefixing conspiracies. . . . If such a shift is to be made, it must be done by the Congress." United States v. Socony-Vacuum Oil Co., 310 U.S. 150, 221-2 (1940).

The Court has repeatedly pointed out that the Sherman Act applies to every form of interstate commerce. See Atlantic Cleaners \& Dyers v. United States, 286 C.S. 427, 434-5 (1932); United States v. Frankfort Distilleries, Inc, 324 U.S. 293, 298 (1945); United States v. South-Eastern Underwriters Ass'n, 322 U.S. 533, 553, 5t9-1 (1944). Repeals by implication are not favored. United States v. Borden Co., 303 U.S. 18S, 198-9 (1939). This is particularly true with regard to "implied" exemptions from the Sherman Act. See United States v. Socony-Vacuum Oil Co., 310 U.S. 150, 225-S (1919); Schwegmann Bros. v. Calvert Distillers Corp., 341 U.S. 384, 395 (1951). Regulated industries are not per se exempt from the Sherman Act. Georgia v. Pennsylvania R.R, 324 U.S. 439,456 (1945). Wherever Congress wished to grant exemption from the Shorman Act to particular businesses, groups, or practices it did so in clear, express, and definite terms. E.g., $\$ 6$ of the Clayton Act, 38 STAT. 731 (1914), 15 U.S.C. $\$ 17$ (1946) (હะempting labor organizations); Webb-Pomerene Act, 40 ST.AT. 516 (1918), 15 U.S.C. 82 (1946) (exempting associations of producers engaged in export trade); Walter-McCarran Act, 59 Stat. 33 (1945), 15 U.S.C. $\$ 1012$ (1946) (limited exemption of insurance); Reed-Bulwinkle Act, 62 Star. 472 (1948), 49 U.S.C. \& 5b(9) (Supp. 1952) (evemititin of rate agreements among carriers). And when Congress wishcd to grant exemption to certain activities in the field of securities, it did so in similarly precise terms. $\$ 15 \mathrm{~A}(\mathrm{~m})$ of the Maloney Act, 52 STAт. 1075 (1938), 15 U.S.C. $\$ 780-3$ (1946) (limited excmition for the rules of associations of securities dealers).

47. Shortly after the Antitrust Division filed its brief in the Nalional Ass's of Securities Dealers case, Congressman Reece introduced two bills to grant such exumptions. H.R. 5233, 78th Cong., 2d Sess. (1944) ; H.R. 1626, 79th Cong., 1st Sess. (1945). Both bills died in committee. The court in the instant case stated that this orcurred because the exemptions would have been too broad. United States v. Margan, Cin il No. 43-757, S.D.N.Y., October 17, 1953 [p. 146 Record Press]. But of. Beurgia v. Pennsylvania R.R., 324 U.S. 439,457 (1945).

48 . See notes 44,46 supra. 